\title{
Agricultural and Economy-Wide Effects of European Enlargement: Modelling the Common Agricultural Policy
}

\author{
C. F. Bach, S. E. Frandsen and H. G. Jensen
}

The economic impact of extending the Common Agricultural Policy to the Central and Eastern European countries (CEEC) has become a major issue in the European enlargement debate. This paper addresses this issue by providing an assessment of the economy-wide effects of European enlargement using a global general equilibrium model where special attention is given to modelling the instruments of the Common Agricultural Policy, the Agenda 2000 proposal and the EU budget. The results indicate a substantial potential for increasing agricultural production in the CEEC. The EU budget will increase significantly and the transfers from EU taxpayers to farmers in the CEEC result in significant welfare gains in the new member countries. In spite of these important transfers the macroeconomic costs for the EU are found to be limited.

\section{Introduction}

The preparations for the enlargement of the European Union (EU) to include the Central and Eastern European Countries (CEEC) have begun and it seems realistic that several Central and Eastern European Countries will have joined the EU by the year 2005.

This impending enlargement has initiated a number of studies attempting to assess the possible impact of an enlarged EU. As the Common Agricultural Policy (CAP) remains a cornerstone of EU co-operation and the CEEC are expected to have a comparative advantage in agriculture, a number of these studies, as well as the present study, focus on agriculture. This is because an eastward enlargement with the 10 CEEC will expand the Union's agricultural area by 52 per cent, increase production and competition on the European market as well as on the world market. This could also affect future negotiations on agriculture within the World Trade Organisation (WTO). Furthermore,

Christian F. Bach is at the Institute of Economics, University of Copenhagen; Søren E. Frandsen and Hans G. Jensen are at the Danish Institute of Agricultural and Fisheries Economics. The authors wish to thank Alan Matthews, Chantal P. Nielsen and two anonymous referees for valuable comments and suggestions. 
an enlargement within the current agricultural policies could have major impacts on the EU budget. Previous studies dealing with the EU/CEEC integration include Brenton and Gros (1993); Tyers (1993,1994); Tangermann and Josling (1994); Anderson and Tyers (1995), Slater and Atkinson (1995), European Commission (1995) and Tangermann (1996). However, these are all partial equilibrium studies that disregard potentially important linkages between agriculture, services and manufactures. Furthermore, only the European Commission (1995) takes into account the impact of the Uruguay Round. Multi-region computable general equilibrium (CGE) studies include Hertel et al. (1997b). However, Hertel et al. do not explicitly capture important elements of the 1992 CAP reform, such as the set-aside premiums and the milk quotas, or tackle the important question of whether the value-based or the quantitative restrictions of the Uruguay Round Agreement will become binding. Furthermore, the study is undertaken with a rather limited commodity structure, which is ill suited to the detailed commodity specification of the agricultural commitments of the Uruguay Round Agreement and the Agenda 2000 reform proposal. Baldwin et al. (1997) also use a multi-regional general equilibrium model but with a very stylised implementation of the CAP and no endogenous budget allocation.

Moreover, the previous studies have failed to assess the integration process in a projection mode and to take the EU Commissions Agenda 2000 proposal into account. These aspects are important in order to capture the interaction between structural changes and policy reforms in the period prior to accession.

This paper deals explicitly with several of these aspects by giving special attention to an extended representation of the Common Agricultural Policy, the GATT Commitments and the Agenda 2000 proposal within a global general equilibrium model, where the world economy is projected to the year 2005. This allows us to evaluate the agricultural and economy-wide effects of an EU enlargement with and without the Agenda 2000 proposal in place and to assess the economic and budgetary effects of integrating the Central and Eastern European Countries into the EU.

The rest of the paper is organised as follows. In Section 2 a description of the applied methodology is given focusing on, the theoretical model, the database, the representation of the CAP instruments and projection of the database. Section 3 introduces the experimental design. Section 4 contains the results of the simulations and Sections 5 and 6 discuss the validity of the results and the conclusions, respectively. 


\section{Methodology}

\section{Model Description}

This study is based on the GTAP applied general equilibrium model of the world economy (cf. Hertel, 1997a) and the GTAP global database (cf. MacDougall, 1998). The base year is 1995. Both the model and database have, however, been modified and specifically tailored to this study.

The model used is a relatively standard multi-regional, static CGE model. Regional production is produced according to a constant return to scale technology in a perfect competitive environment and the private demand system is represented by a non-homothetic demand system (a Constant Difference Elasticity function). The foreign trade structure is charactorised by the Armington assumption implying imperfect substitutability between domestic and foreign goods.

The macroeconomic closure in the model used is a neo-classical closure where investments are endogenous and adjusts to accommodate any changes in savings. This approach is adopted at the global level and investments are then allocated across regions to equalise the marginal rate of return in all regions. Although global investments and savings must be equal, this does not apply at the regional level, where the trade balance is endogenously determined as the difference between regional savings and regional investments. This is valid as regional savings enter the regional utility function. The numéraire use in the model is a price index as suggested by de Melo and Robinson (1989) and de Melo and Tarr (1992), specifically the global primary factor price index.

The approach taken allows us to focus on the institutional features of the Uruguay Round, the instruments of the Common Agricultural Policy and the Agenda 2000 proposal. We therefore abstract from features like imperfect competition and increasing return to scale. An example of a model with such characteristics can be seen in Hertel et al. (1997b).

\section{Modifications to the GTAP model}

In order to be able to capture the effects of important institutional features of the CAP and the Uruguay Round Agreement, the GTAP model has been modified in a number of ways with special attention given to the modelling of:

1) Import and export policies: import tariff reductions and value and quantity based restrictions on export subsidies;

2) Compensatory payments to arable land and livestock, together with set-aside requirements and base area restrictions; 
3) Milk and sugar quotas;

4) The European Union budget and the important effects of future inter-regional transfers between the EU and the CEEC.

Import tariffs and export subsidy rates are adjusted in line with the Uruguay Round Agreement offers, and fixed at the agreed rates according to the Uruguay Round Agreement if these rates are binding. We also abolish the mechanism of variable import levies and variable export subsidy rates in the EU as these clearly are against the spirit of the GATT Agreement, cf. (GATT, 1994a).

The initial 1995 (average effective) tariff data in the database is therefore compared with the actual WTO tariff schedules and in those cases where the 1995 protection rates exceed the tariff schedules we reduce the rates to the bound rates agreed upon in the Agreement. With respect to the minimum access requirements it is important to note that neither the current nor the minimum access tariff rate quota constitute a minimum purchase agreement. They provide only the 'opportunity' to import under the advantages of a preferential or suspended tariff. This 'opportunity' is provided given the reduced average effective tariff rates implemented in our study.

In contrast to earlier studies on the Uruguay Round Agreement, we follow the precise commitments and target the value of export subsidies and not just the export subsidy rate. Moreover, we assess whether it will be the quantitative or the value based export requirements for agricultural subsidies that will be binding in the Uruguay Round Agreement.

Total export subsidies, $E_{i, r}$, associated with the export of good $i$ from region $r$ to other regions (s) are given by:

$$
E_{i, r}=\sum_{s}\left(p_{i, r}^{m}-p_{i, r, s}^{f o b}\right) \cdot q_{i, r, s}^{x s}=\sum_{s}\left(t_{i, r, s} \cdot q_{i, r, s}^{x s}\right)
$$

where $p_{i, r}^{m}$ is the market price in region $r, p_{i, r, s}^{\text {fob }}$ is the destination specific world price, f.o.b., $q_{i, r, s}^{x s}$ is the quantity exported to region $s$ and $t_{i, r, s}$ is the destination specific export subsidy rate.

According to the Uruguay Round Agreement the value of export subsidies for each commodity, $E_{i, r}$ has to decline by 36 per cent from the Uruguay Round base period value, while the total export volume, $\sum_{s} q_{i, r, s}^{x s}$, must decline by 21 per cent. In most previous studies of the Uruguay Round (see Martin and Winters, 1996) this has been implemented by bluntly cutting the export subsidy rates, $t_{i, r, s}$, by 36 per cent. Instead, we modify the model in order to assess carefully, which 
of the actual restrictions that will be binding when projecting the 1995 database to 2005 . That is, we compare the simulated value of export subsidies and quantities with the commitments as outlined in the Uruguay Round Country Schedules (GATT. 1994b).

The system of intervention and guaranteed prices is not explicitly modelled in this study but implicitly represented through the setting of border protection rates. We have chosen this strategy deliberately, as the main (sustainable) mechanism in the long run is border protection and not storage (which the EU Commission also recognises in for example the Agenda 2000 proposal). This approach also gives us an opportunity to illustrate to what extent and in which markets an increased competition from Central and Eastern European farmers potentially could affect future production in EU-15 if storage (intervention) and border protection are unchanged. Or to put it differently - in which markets the EU following an enlargement would have to change intervention prices so as to avoid possibly large increases in the level of intervention stocks in the European Union.

The compensatory payments, the set-aside requirements and the definition and size of the base areas are all important elements of the EU grain policy. To the best of our knowledge this is the first attempt to assess the eastern enlargement while incorporating these effects in a general equilibrium, multi-regional model.

The compensatory payments to land are implemented as input subsidies to agricultural land ${ }^{1}$. The resulting hectare premiums are introduced in the model by the following definition:

$$
p l_{j, r}=p l_{j, r}^{f}+h p_{j, r,} \quad j \in A G R, r \in R E G
$$

where $p l_{j, r}$ is the market price of agricultural land used by sector $j$ in region $r, p l_{j, r}^{f}$ is the land price paid by farms and $h p_{j, r}$ is the sector specific hectare premium per hectare. The total budgetary expenditure on hectare premiums by sector is given by:

$$
H P_{j, r}=h p_{j, r} \cdot q_{j, r}^{f} \text {, }
$$

1 As described in McDougall (1998) all direct subsidies to agriculture in the OECD countries are based upon the OECD PSE tables for 1995. In the GTAP database these subsidies are represented as output subsidies. However, the compensatory payments to land in the EU which constitute a significant share of the overall direct subsidies, are not linked directly to production. Therefore, in the initial GTAP database input subsidies to land are added (hectare premiums) and output subsidies are adjusted to provide a more accurate measure of direct support. 
where $q_{j, r}^{f}$ is the input of agricultural land including set-aside, into sector $j$ in region $r$, multiplied by the sector specific hectare premium $h p_{j, r}$.

In our initial database we calibrate $h p_{j, r}$ such as to comply with the compensatory rates paid to reform crops and set-aside in the European Union in 1995. At the same time, we also calibrate $q_{j, r}^{f}$ to the historic levels of land used in sector $j$ in 1995 inclusive the required set-aside rate of land ${ }^{2}$.

Finally, the total area for which compensatory payments can be requested in the European Union is restricted to the total base area of 53,563,000 hectares of land. In order to be able to check this restriction we introduce the following equation into the model:

$$
Q_{r}=\sum_{j} q_{j, r}^{f}
$$

where $Q_{r}$ is the total area receiving compensatory payments. If $Q_{r}$ exceeds the total base area of the European Union hectare premiums are reduced proportionally in line with the overshoot of the total base area.

The implementation of compensatory payments to land is modelled by fixing the hectare premium per hectare and allowing land to adjust endogenously between the reform crops given that the European Union's base area is not exceeded.

In the special case of oilseeds, however, the Blair House agreement puts a specific restriction on the grown area of oilseeds, namely 5,482,000 hectares including set-aside within the total area $Q_{r}$ of the European Union. In 1995 this base area for oilseeds was exceeded, forcing the European Union to reduce compensatory payments per hectare given to oilseeds proportionally with the amount of excess land used.

This implies that with the Blair House agreement in force, we have modelled compensatory payments to oilseeds by fixing the total budget expenditure on compensatory payments given to oilseeds while allowing the corresponding hectare premiums to adjust endogenously.

\footnotetext{
2 In 1995 the average set-aside rate in the European Union was 14.4 percent, which on average meant that for every hectare of land where compensatory payments were paid only 0.856 hectare was productive. To change the set-aside rate from 14.4 percent in the 1995 base year we simply increase/decrease the productivity of land used in sector $j$ and recalibrate $h p_{j, r}$, using the new share of land allocated to production and set-aside per hectare.
} 
Similarly, we model compensatory payments to livestock as input subsidies in the case of suckler cow and breeding ewe premiums ${ }^{3}$. In the case of male animal and steer premiums we have chosen to model these premiums as output subsidies to livestock production. This difference in implementing compensatory payments to livestock reflects the fact that suckler cows and breeding ewes are a part of the production capital used to produce slaughter animals, while male animals and steers are final products sold directly to the slaughter houses.

The implementation of compensatory payments to suckler cows, breeding ewes, male animals and steers are modelled in the same manner as oilseed premiums, namely by fixing the total EU budgetary expenditure on premiums paid and allowing premiums per cow/ewe and male animal/steer to adjust endogenously. This is done because the ceiling on premium rights for breeding ewes, male animals and steers were fully utilised in the European Union in 1995, while for suckling cows the utilisation of rights was just below the total amount of premium rights, cf. (European Commission 1997b).

Raw milk and sugar beet quotas in the European Union are introduced into the model by the following price link:

$$
P M_{i, r}=\left(1+T_{i, r}^{o}+T_{i, r}^{q}\right) \cdot P S_{i, r}
$$

where $P M_{i, r}$ is the market price of commodity $i$ in region $r, P S_{i, r}$ is the pre-tax supply price and $T_{i, r}^{o}$ is an output tax rate and $T_{i, r}^{q}$ is the quota tax rate. For the raw milk and sugar beet sectors $T_{i, r}^{q} \cdot P S_{i, r}$ is interpreted as the quota rent of raw milk/sugar beet respectively. In the initial 1995 database $T_{i, r}^{q}>0$ for the raw milk and sugar beet sectors, reflecting a positive quota rent in both these sectors in 1995, while for all other sectors $T_{i, r}^{q}$ is equal to zero ${ }^{4}$.

3 In the same manner as compensatory payments to land, output subsides are adjusted and input subsides are added in the GTAP database to represent compensatory payments to livestock.

4 The existence of sugar and milk quotas in 1995 and the corresponding quota rents should be reflected in the database. Quota rents are therefore in these cases introduced into the database as wedges between the value of output at producer prices and the value of output at marked prices. The initial value of sugar and milk quota rents incorporated for the EU is estimated to be 20 per cent of the value of purchases of domestically produced raw milk (sugar beet) by dairy (sugar) firms in the EU. 
The raw milk and sugar beet quotas are implemented in the model by making the quantity of raw milk and sugar beet produced in the European Union exogenous while $T_{i, r}^{q}$ is endogenous allowing the quota rent to adjust to market conditions.

Finally, we implement the budgetary transfers by incorporating a specific budget equation. The financing of the Common Agricultural Policy has been defined so that all expenditures net of all revenues from import tariffs in the EU and the CEEC are financed by the member countries, allowing, however, for transfers from the EU-15 to the CEEC. The transfers from the EU-15 to the CEEC are determined as the sum of

i) Compensatory payments to land and livestock in Central and Eastern European Countries;

ii) Output subsidies funded by the European Agricultural Guidance and Guarantee Fund (EAGGF);

iii) Agricultural export subsidies related to exports from these countries to third countries net of all import tariffs from the CEEC stemming from imports of agricultural products;

iv) The expected GDP contribution from the CEEC. As the CAP consumes approximately 50 per cent of the total EU budget and the future proportion of GDP from member countries is expected to be slightly below 1.3 per cent, the expected GDP contribution is set to 0.65 per cent of GDP.

\section{Data}

The global database used in this study is version four of the GTAP database (MacDougall, 1998). The 1995-database combines detailed bilateral trade, transport and protection data characterising economic linkages among regions, together with individual country input-output data bases which account for intersectoral linkages within regions.

To keep the model within computational limits and focus on the issues of interest, the GTAP database is aggregated to 16 regions and 19 commodities. The CEEC region used in this paper consists of seven countries namely Bulgaria, Czech Republic, Hungary, Poland, Romania, Slovak Republic and Slovenia. Therefore all results presented in this paper reflect the implications of enlarging the European Union with these seven countries under the conditions specified by our experimental design. 


\section{Experimental design}

\section{Baseline projections}

Compared with other multi-region CGE studies of the economic effects of an EU enlargement, e.g. Hertel et al. (1997b), Baldwin et al. (1997), the emphasis of this studies design has been to construct a baseline with a projection of the world economies as they might look in the year 2005 . This is done as it is important to analyse the interactions between economic growth, structural change and policy reforms (see Bach et. al., 1998).

In the period 1995 to 2005 a number of economic and political changes will take place before the enlargement is a reality - some of which will significantly influence the economic consequences of an enlargement. First of all, the baseline constructed in this paper takes into account the economic changes following the full implementation of the GATT Agreement and the 1992 EU agricultural reform. These reforms will change the pattern of production and trade in especially agricultural products. Secondly, economic growth, technological progress and the degree of convergence between the CEEC and the EU in the period before accession will also affect the economic outcome of integrating the CEEC into the EU. Thirdly, in many countries the factor endowments are expected to increase significantly and capital/labour ratios in different countries and industries will change. This will create supply-side pressures for changes in the composition of output in some countries (Rybczynski effects). Finally, differences in income responsiveness of demand for commodities will also affect the net export position of a given country and commodity group.

To construct the projection of the 1995 GTAP database to the year 2005 we shock total population, factor endowments (unskilled labour, skilled labour and physical capital) and total factor productivity (TFP) in crop and livestock sectors which are assumed to be region and sector specific (Bach, 1996). The endowment of land and natural resources are assumed to be constant. The TFP growth rates in all other sectors than agriculture are obtained endogenously by holding GDP targets exogenous in the baseline simulations.

\section{Scenarios}

A total of four scenarios are analysed; the details are summarised in Annex 1. Scenario one represents the baseline for the period 1995 to 2005 incorporating projections of the world economy to the year 2005 as well as the effects of the Uruguay Round Agreement. Besides the changes following the implementation of the GATT Agreement, agricultural and other policies are assumed 
unchanged and kept constant at their 1995-levels in the period 1995 to $2005^{5}$. However, all direct payments in the EU are deflated by 2 per cent per year since the (maximum) budgetary outlays are fixed in nominal terms. Finally, it is assumed, that border taxes between the seven Central and Eastern European Countries are removed (preparation for joining the European Union) ${ }^{6}$.

Scenario two analyses the economic effects of integrating the Central and Eastern European Countries into the European Union and the Common Agricultural Policy in the year 2005 in a world as shaped by scenario one. All tariffs and export subsidies as well as non-tariff barriers between the EU and the CEEC are abolished and all sectors in the CEEC are given the same level of protection against third countries as in the EU. This scenario also extends the CAP policy to the new member countries including the common financing of the agricultural policy and transfers from the EU-15 to pay for export subsidies, output subsidies and hectare and livestock premiums in the new member countries. This also implies for example, that sugar and milk quotas are established on the basis of production levels prior to integration (in 2005) as well as the set aside rate is equalised with the EU-15 rate.

Scenario three is an alternative baseline in which the CAP is reformed according to the Agenda 2000 proposal. This involves reduction in intervention prices for cereals, beef and dairy products by 20,30 and 15 per cent respectively, compensated by increased premiums. The set-aside rate is reduced to zero and the milk quota regime is maintained, supplemented by a 2 per cent increase in the total amount of authorised production. In scenario four the CEEC are integrated (as in scenario two) in a world as shaped by scenario three.

These scenarios allow us to analyse the impacts of different agricultural policies in both the EU and the CEEC while taking into account the general prospects for economic growth. Moreover, it allows us to analyse the interactions between economic growth, structural change and trade reforms in Europe and the rest of the world simultaneously.

\footnotetext{
5 This implies for example that the 1995 changes in US agricultural policies is not taken into account - changes which potentially could influence world price evolution in the period prior to integration and thereby the EU budget costs of accession.

6 This assumption does not in any significant way affect the impacts of the scenarios analysed later. Also, the baseline does not explicitly take into account the effects of the Europe Agreements as these are very restrictive with respect to agricultural trade. However, the baseline does take into account increased trade generally between EU-15 and the Central and Eastern European Countries.
} 
The scenarios: Agricultural protection rates

The initial (1995) and resulting border tax rates and output taxes in 2005 following the two alternative baseline scenarios are shown in Table 1 below. In the first three columns the import tariff equivalents are shown for the base year 1995 as well as the resulting tariff equivalents after projecting the database to 2005 . Correspondingly, the next three columns show the initial and final export tax/subsidy rates.

In the case of wheat, the initial tariff rate in 1995 is relative low due to high world market prices that year. This implies that the EU-15 tariff rate in that year was well below the final post UR commitment on wheat - and therefore no reductions in the tariff rate is required. However, the export subsidy rate for wheat (initially 12.4 per cent) is reduced in the baseline to zero due to quantitative restrictions on subsidised exports of wheat from EU-15 in accordance with the European Community's UR schedule on commitments limiting subsidisation, cf. (GATT 1994b). ${ }^{7}$

In the case of other grains and other crops the same pattern emerges where post UR tariff rates are not binding but export subsidy rates have to be reduced due to quantitative or value commitments in the European Community's UR schedule.

In the case of bovine animals and bovine meat products, the post UR tariff rates are binding wherefore both border tax rates are reduced accordingly. Note also that the export subsidy rates are adjusted accordingly in order to avoid the situation where the import tariff rate is below the export subsidy rate (resulting in a "money machine" effect).

In scenario 3, the Agenda 2000 baseline, the border protection rates differ from scenario 1, as we have chosen to represent reductions in intervention prices by reducing protection rates for wheat, other grains, bovine animals and meat products and dairy products.

7 In 1995 according to the European Communities notification concerning export subsidy commitments to the World Trade Organisation the EU15 exported 10.8 million tons of wheat, which is below the EU15's final quantity commitment on total subsidised wheat exports of 14.4 million tons, cf. (WTO 1998). Under the assumption that all wheat export from the EU15 is subsidised in the projection of the database to 2005, the growth of subsidised wheat exports is only allowed to expand by 33 percent. But with this restriction imposed in the projection of the database, the European Community - given the increased global demand for wheat in the baseline - has to tax exports of wheat to remain within the quantity commitment. Therefore, we eliminate wheat export subsidies, cf. Table 3. 
Table 1. Border protection and output subsidies for agriculture, EU-15, per cent.

\begin{tabular}{lrrrrrrrr}
\hline & \multicolumn{2}{c}{ Import tariff equivalent } & \multicolumn{2}{c}{ Export subsidies } & \multicolumn{2}{c}{ Output subsidies } \\
& Base & S-1 & S-3 & Base & S-1 & S-3 & Base/S-1 & S-3 \\
& 1995 & 2005 & 2005 & 1995 & 2005 & 2005 & $1995 / 05$ & 2005 \\
\hline Wheat & 12.4 & 12.4 & 0.0 & 12.4 & 0.0 & 0.0 & 6.2 & 6.2 \\
Other grains & 44.2 & 44.2 & 15.4 & 44.2 & 25.3 & 15.4 & 5.0 & 5.0 \\
Vegetables, fruit, nuts & 5.5 & 5.5 & 5.5 & -1.0 & -1.0 & -1.0 & 1.0 & 1.0 \\
Oilseeds & 0.0 & 0.0 & 0.0 & 0.0 & 0.0 & 0.0 & 8.9 & 8.9 \\
Sugar cane and beet & 76.6 & 76.6 & 76.6 & 76.6 & 76.6 & 76.6 & -2.7 & -2.7 \\
Other crops & 9.1 & 9.0 & 9.0 & 2.9 & 2.5 & 2.3 & -0.1 & -0.1 \\
Bovine animals & 111.2 & 75.6 & 47.7 & 111.2 & 75.6 & 47.7 & 10.5 & 28.2 \\
Other animal products & 0.8 & 0.6 & 0.6 & 18.7 & 10.9 & 10.4 & 9.0 & 9.0 \\
Raw milk & - & - & - & - & - & - & 8.9 & 16.2 \\
Wool & 0.0 & 0.0 & 0.0 & 0.0 & 0.0 & 0.0 & 24.9 & 24.9 \\
Resource extraction & 0.2 & 0.1 & 0.1 & -0.6 & -0.6 & -0.6 & 0.4 & 0.4 \\
Bovine meat products & 111.2 & 75.6 & 47.8 & 111.2 & 75.6 & 47.8 & 0.6 & 0.6 \\
Other meat products & 18.7 & 18.7 & 18.7 & 18.7 & 18.7 & 15.7 & 0.7 & 0.7 \\
Dairy products & 116.3 & 116.3 & 83.9 & 116.3 & 116.3 & 83.9 & 1.0 & 1.0 \\
Sugar & 76.6 & 76.6 & 76.6 & 76.6 & 76.6 & 76.6 & 0.8 & 0.8 \\
Other proc. food prod. & 9.3 & 9.3 & 9.3 & -0.1 & -0.1 & -0.1 & -7.4 & -7.4 \\
\hline Sourcer GTAP 4. & & 9.3 & & &
\end{tabular}

Source: GTAP 4 database, Ingco (1995) and own calculations.

Note: See Annex 1 for a description of the scenarios.

Including the CEEC in the EU will lead to substantial increases in the CEEC agricultural protection rates against third-country suppliers. With the Agenda 2000 in place output and input subsidies will also increase significantly in the CEEC upon accession. Import tariffs and subsidies to exports increase for especially grains, sugar, bovine meat and dairy products without the Agenda 2000 proposed reforms and much less so if the Agenda 2000 proposal is implemented. In the case of vegetables, fruit and nuts, oilseeds, other animal products, other meat products (pig- and poultry meat) and other processed food products, the pre-enlargement border protection rates in the CEEC are according to the database and the GATT Agreement above EU-15 levels. Therefore, integrating the CEEC in the CAP leads to reductions in border protection rates for these products.

\section{Results $^{8}$}

In presenting the results we will focus on production, the implications for the EU budget and regional welfare of the EU and CEEC. Further results can be found in Jensen et al. (1998).

\section{Production}

Changes in output are determined by the assumed productivity increases, export and import growth 
rates, and the growth in domestic private consumption shaped by income growth and the assumed income elasticities. The resulting production changes in the European Union are given in Table 2.

The baseline (scenario 1) reflects the structural shift in the composition of European Unions production as the importance of agriculture and the agricultural processing industry declines relative to manufacturing and more capital-intensive industries. During the period of consideration the production of wheat and other grains in the EU increases slightly whereas the production of oilseeds and other crops increases by more than 30 per cent. This shift reflects the assumed relative profitability among the crop sectors following the implementation of the Uruguay Round with lower export subsidies for wheat and other grains. The production of sugar is assumed limited by the EU sugar quota regime. The production of industrial goods and services is projected to increase by around 2 per cent annually.

In the animal sectors particulerly the production of bovine animals is affected by the full implementation of the Uruguay Round Agreement as the protection rate in 1995 is significantly higher than the EU post UR binding commitment (protection is reduced to the final rate in the year 2000). The production of bovine animals falls by around 12 per cent. The EU dairy policy is assumed unchanged during the period 1995 to 2005 resulting in no changes in the quantity of raw milk produced. The production of wool is more than doubled, which is explained by an increased global demand for wool products caused by an increased regional income growth and the relatively large income elasticity for wool found in most regions.

In scenario 3 we supplement scenario 1 with the Agenda 2000 proposal. Comparing the results we generally find only small changes in the production of the individual agricultural commodities with the exception of other grains (lower import tariffs and export subsidies) and bovine animals and bovine meat products (significantly lower border protection). The production of raw milk/quota increases in the EU by 2 per cent as outlined in the proposal. The production of wheat, oilseeds and other crops increases slightly as the profitability of these products increase relative to the production of other grains (land is reallocated accordingly) ${ }^{9}$.

\footnotetext{
9 It is noted that these projections seem to agree quite well with the latest long term 1998-2005 commodity projections form the Commission (1998).
} 
Table 2. Change ${ }^{*}$ in output, per cent

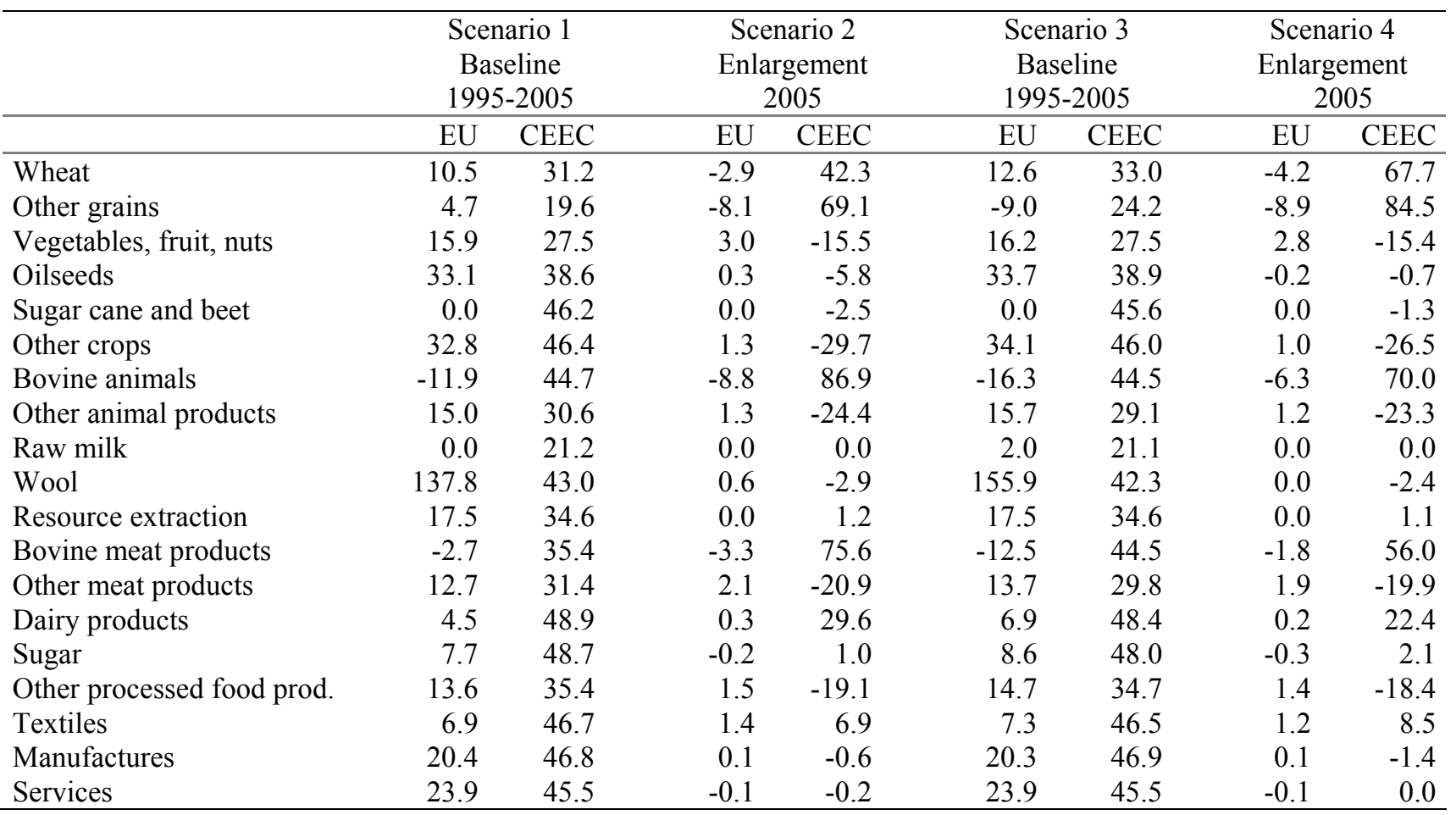

* The results for scenario 1 and 3 are presented as accumulated changes during the period 1995-2005, while scenario 2 and 4 are reported as changes relative to scenario 1 and 3, respectively.

Integrating the CEEC into the EU, scenario 2, leads to a 3 and 8 per cent decrease in the production of wheat and other grain products in the EU-15 relative to what the production would have been in the absence of enlargement. The production of bovine meat products falls by 3.3 per cent while the milk quota keeps the production of raw milk unchanged. For a number of industries production increases as a result of increased export to the Central European Countries. At first, the 3 per cent increase in the production of vegetables, fruit and nuts in EU-15 are a surprise. However, production of these products declines by 15.5 per cent in the new member countries as the relative protection of these commodities are reduced (lower border protection for vegetables and fruits relative to higher border protection for grains and hectare premiums to the reform crops). Agricultural land is reallocated accordingly to equalise the return to land.

Table 2 also illustrates the changes in the pattern of production in the CEEC prior to enlargement. Integrating the CEEC into the EU changes this pattern dramatically within agriculture at the expense of the other industries. Note, also that the production of raw milk in the CEEC is limited by a production quota corresponding to the level of production in the year of integration (2005), whereas the quota for sugar cane and beet is found not to be binding (lower than their 2005 level of 
production $)^{10}$. Production of manufacturing and services is affected negatively as a result of factor reallocations following the integration of the countries into the EU. This is also a logical consequence of the reduction of protection for these products as tariffs are harmonised (higher initial tariffs in the CEEC). An exception is the textiles and clothing industries where integration spurs further production growth in the CEEC.

Reforming the Common Agricultural Policy according to the Agenda 2000 proposal prior to enlargement does not significantly change the impact of enlargement on the European structure of production. However, the reforms seem to stimulate the production of grains and oilseeds further due to the assumed extension of the hectare premiums to the new members in spite of lower border protection for wheat and grains ${ }^{11}$. Contrarily, the expansionary effect on the production of bovine meat and dairy products in the CEEC is clearly smaller as the border protection is significantly lower after the Agenda 2000 proposal. These impacts on the individual activities in the new member countries reflect the balances between on the one hand the changes in relative border protection rates and the implemented compensatory payments and on the other hand the effects on consumption and the secondary effects through the factor markets.

Finally, production of industrial goods in the Central and Eastern European Countries falls by 1.4 per cent in scenario 4 as compared to 0.6 per cent in scenario 2 . The opposite result is found for services where production is now unchanged opposed to a small loss of 0.2 per cent in scenario 2 . The extent to which the remaining industries are affected by the extension of the CAP depends, as demonstrated, on the design of agricultural policies and on the importance of e.g. labour and capital in total costs as well as differences in exposure to international competition in the two industries.

\section{The EU budget}

The total budgetary burden for the EU is shown in Table 3. Total transfers to the Central and Eastern European Countries as a result of the CAP amount to 1995-ECU 11.3 billion. This includes expenditures to compensatory payments, output subsides and export subsidies net of tariff revenue collected on imports into the CEEC and their GDP contribution to the financing of the Common

\footnotetext{
$10 \mathrm{We}$ are of course aware that the exact quota level for raw milk and sugar cane and beet as well as the base area for which hectare premiums will be given is subject to the enlargement negotiations.

11 It is noted that the per hectare premium in the new member countries are different in scenario 2 and 4 as the hectare and livestock premiums are implemented as a maximum budgetary outlays based on a historical base area. Therefore, per hectare premiums are endogenous and determined to the extent that the grown area exceeds the base
} 
Agricultural Policy. Taking into account changes in costs to export subsidies and the lower import tariff revenues in the EU-15, the total impact on the EU budget amounts to almost ECU 14 billion. This amounts to 35 per cent of the (counterfactual) expenditure level related to the CAP in the year 2005. If the CAP is reformed as proposed in Agenda 2000 - reduced border protection for grains and significant reductions in support for dairy and bovine meat products supplemented by compensatory payments - the transfer to the CEEC increase by ECU 750 million to a total of ECU 12 billion. Including saved export subsidies and lost revenues from import tariffs in the EU-15, the total impact on the EU budget is still almost ECU 14 million, corresponding to 32 per cent of the counterfactual EU expenditure level in 2005. Note that this estimate does not include other important aspects of the EU budget, especially costs associated with the structural funds.

Table 3. Changes in the EU budgetary costs, million 1995 ECU

\begin{tabular}{lrr}
\hline & Scenario 2 & Scenario 4 \\
\hline CAP costs in the CEEC & 13702 & 14417 \\
Tariff revenue and GDP contributions, the CEEC & -2447 & -2412 \\
\cline { 2 - 2 } Total transfers to the CEEC & 11255 & 12006 \\
Changes in costs to export subsidies in the EU-15 & 94 & -38 \\
Lower tariff revenue in the EU-15 & 2554 & 1852 \\
Total change in the EU budget & 13904 & 13819 \\
\hline
\end{tabular}

Hertel et al. (1997b) find that the total change in the EU budget amounts to 1992-ECU 0.4-1.2 billion which is less than a tenth of our estimate. This is due to different assumptions especially regarding the CAP instruments. Most importantly we take the compensatory payments into account and assume that they will also be extended to the new member countries. It would be politically very difficult to have two different versions of a "Common" Agricultural Policy within the same Union and the recent debate regarding a re-nationalisation of part of the agricultural support does reflect budgetary concerns related to the future enlargement. Furthermore our study is undertaken in a projections mode allowing for changes in factor endowments and some degree of convergence of incomes in Europe prior to accession. This also means that our study is based on larger Armington elasticities, which imply substantially greater supply response in the CEEC.

The European Commission, (1995) finds the CAP budgetary costs of integrating all 10 Central and Eastern European countries to be ECU 12 billion, which is close to our estimate. Other recent 
estimates of the CAP budgetary impact of integrating the Czech and Slovak Republic, Hungary, and Poland have been in the range of ECU 5 to 15 billion (Tangermann and Josling, 1994; Slater and Atkinson, 1995; Tangermann, 1996). Adding the costs of including Slovenia, Bulgaria and Romania would, based simply on relative population size, add another 50 per cent to these estimates and still place our estimate within the range.

\section{Welfare consequences}

More important than budgetary implications should be the overall welfare implications (although it sometimes appears as if policy makers value the budget over total economic welfare). These welfare effects include changes in allocative efficiency, terms of trade, inter-regional transfers and contributions from other factors (changes in endowments, technical changes and effects from nonhomothetic preferences). The welfare effects are shown in Table 4.

In total, the CEEC are estimated to gain a welfare improvement of ECU 11.9 billion (measured as the money metric value of the Equivalent Variation) following integration with the existing CAP. This corresponds to a welfare gain of 4.6 per cent. If the agricultural policy is reformed according to the Agenda 2000 proposal, almost the same welfare gain is found (ECU 12.1 billion).

The overall welfare loss for the EU-15 is estimated to be ECU 12 billion in both enlargement scenarios covering the economic impacts of both trade creation and trade diversion effects as well as the cost associated with transfer of income from the EU-15 citizens to the CEEC farmers. This corresponds to a loss of income of 0.2 per cent. Decomposing the losses for the EU and the gains for CEEC illustrates that the story told is primarily a question of redistribution from Western European tax payers to Eastern European farmers. The total cost for EU-15 of ECU 12 billion in scenario 2 consists of a loss of 11.3 billion caused by the need for interregional transfers, an efficiency gain of almost ECU 1 billion and a term of trade loss of ECU 1.7 billion.

Baldwin et al. (1997) estimate real income gains in the CEEC from integration to be ECU 2.5 billion (1992 prices) in their conservative case and ECU 30.1 billion in their less conservative case (which, however, should be carefully interpreted, see Rodrik, 1997). For the EU they find a real income gain of ECU 9.8 billion, which contrasts our welfare loss. Their stylised representation of the CAP and lack of an endogenous budget allocation clearly explains this.

For the remaining non-member regions considered in this analysis we find only very small welfare effects (for a detailed discussion of the welfare implication of a European enlargement on nonmember regions see Frandsen et al., (1998)). 
Table 4. Change in economic welfare, million, 1995 ECU

\begin{tabular}{lrr}
\hline & Scenario 2 & Scenario 4 \\
& 2005 & 2005 \\
\hline European Union (15) & $\mathbf{- 1 1 9 8 0}$ & $\mathbf{- 1 2 0 0 1}$ \\
$\quad$-of which & & 769 \\
$\quad$ Allocative efficiency gains & -1742 & -933 \\
$\quad$ Terms of trade effects & -11265 & -12016 \\
$\quad$ Transfers & 156 & 180 \\
$\quad$ Other effects & & $\mathbf{1 1 9 2 6}$ \\
& & $\mathbf{1 2 1 0 0}$ \\
Central and Eastern European Countries & 119 & -28 \\
-of which & 1657 & 1019 \\
$\quad$ Allocative efficiency gains & 10735 & 11502 \\
$\quad$ Terms of trade effects & -586 & -393 \\
$\quad$ Transfers & & \\
Other effects & & \\
\hline
\end{tabular}

Note: Economic welfare is measured as the money metric value of the Equivalent Variation. 'Other effects' include welfare changes due to changes in endowment, technical changes, and effects from the non-homothetic preferences.

It is important to note that these welfare effects only tell part of the story. Most importantly we have not accounted for the possible dynamic effects of integration such as enhanced capital accumulation and higher productivity growth. The implications for investments could be substantial due to a reduction in the risk premium in the CEEC following a more stable and predictable environment (Baldwin et al., 1997). Another factor not accounted for is a reduction in trade costs due to the adoption of uniform rules and procedures, which, however, has a mirror image in the higher costs needed to raise standards in the CEEC.

\section{Qualification}

Besides modelling the CAP instruments the structure of the model in general is important for e.g. the size of the welfare implications of integrating the Central and Eastern European Countries. Using a relatively standard neo-classical structure assuming constant returns to scale technologies, perfect competition and no income-investment linkages implies lower welfare effects from trade reforms as compared with models that incorporate scale economies, imperfect competition and accumulation effects. These effects are important features in the literature on the U.S.-Canada Free Trade Agreement (Cox and Harris, 1985), the NAFTA (Francois and Shiells, 1994) and European Integration (Venables and Smith, 1988; Baldwin, 1992, Hertel et. al, 1997b).

Trade flows, production levels and budgetary implications of integrating the Central and Eastern 
European Countries into the CAP also depend upon the Armington specification and the size of the trade elasticities. Generally, models with Armington specifications yield smaller trade and output effects than models with homogenous goods or models with firm-level product differentiation (see Francois et al., 1996). The elasticities used in this study with respect to the agricultural products are typically around 9 for the import nest between different regions and around 4.5 between the domestic commodity and (a composite of) imports. Naturally, if these elasticities are reduced the increases in the CEEC production and exports of agricultural products are correspondingly smaller when integration takes place. This in turn would lead to smaller budgetary costs of integrating the CEEC. The chosen level of aggregation also matters for the results found, cf. Gehlhar and Frandsen (1998).

Sensitivity analysis indicate that the budgetary costs of integrating the Central and Eastern European Countries are reduced by approximately 10 per cent to ECU 12.3 billion when trade elasticities are halved. Moreover, if we assume that the hectare and animal premiums are not extended to the new member countries - although difficult to envisage given the present policy the budgetary cost of an enlargement would be reduced to 6.9 ECU billion compared to the ECU 13.9 billion reported earlier.

As noted earlier the projections do not explicitly deal with the Europe Agreements as these are very restrictive with respect to agricultural trade. However, to the extent that they provide some access prior to full membership for the CEEC farmers to EU prices the calculated costs of accession might be slightly exaggerated.

Further, in the accession scenarios consistency with EU22 WTO disciplines has not been dealt with explicitly in this paper. These aspects could potentially be important issues in the WTO discussions related to European Enlargement between the European Countries and a number of other WTO contracting parties. Some of these aspects are dealt with explicitly in Frandsen et. al (1998).

Our attempt to represent the institutional features such as the Common Agricultural Policy in a general equilibrium model illustrates the importance and difficulties in representing these aspects correctly. Combined with other assumed initial distortions these features do affect the quantitative implication of for example an EU enlargement. 


\section{Concluding remarks}

The focus of this analysis has been to assess the effects of integrating the Central and Eastern European Countries into the EU, with detailed modelling of the CAP and the Uruguay Round Agreement and with projections to the year 2005. Addressing the integration issue in a projections mode is essential in order to capture the economic growth and structural changes before integration. The specific modelling of the EU agricultural policy instruments allows us to capture the important implications of the Uruguay Round commitments, export subsidies, set-aside requirements, compensatory payments and the milk and sugar quota.

Our findings support the need for more detailed work on global trade reforms. The value-based implementation is not a sufficient representation of the Uruguay Round Agreement. Allowing for the quantitative aspects of the outcome of the Round on both the import and export side is important. Furthermore evaluations of multilateral trade reforms need to be taken into account when evaluating possible CAP reforms such as the Agenda 2000 proposal.

The Central and Eastern European Countries have a solid potential for increased production of both agricultural and labour-intensive manufacturing products. If the CEEC are integrated into the present Common Agricultural Policy of the EU it will significantly boost agricultural production and reallocate resources out of manufacturing and services. The Agenda 2000 proposal does not seem to change this pattern as the reductions of border protection in the EU for highly protected commodities are supplemented by increased compensatory payments. Our analysis supports the view that an enlargement of the EU where border protection and compensatory payments are extended to the new members will have significant supply effects in the new member countries.

Enlarging the EU to include the CEEC in the present or even a reformed agricultural policy along the lines of the Agenda 2000 proposal is an expensive option in budgetary terms. It is found that the expenditure level related to the CAP could increase by about a third. In spite of these higher budgetary expenditures the current EU countries are estimated to loose only 0.2 per cent of their national income. Overall economic welfare improves significantly in the Central and Eastern European Countries following accession and the gain for these countries is estimated to an annual welfare increase of 4.6 per cent.

While these estimates may shed additional light on the economic implications of an eastward enlargement of the European Union, they are, of course, dwarfed by the historical and political importance of creating a united and peaceful Europe. 


\section{References}

Anderson, K. and Tyers, R. (1995). Implications of EU Expansion for European Agricultural Policies, Trade and Welfare, Chapter 9 in Baldwin, Haaparanta and Kiander (Eds): Expanding Membership of the European Union. Cambridge: Cambridge University Press.

Bach, C. F. (1996). A small note on Total Factor Productivity in agriculture. Danish Institute of Agricultural and Fisheries Economics. Copenhagen. Mimeo.

Bach, C. F., Dimaranan, B., Hertel, T. and Martin, W. (1998). Market Growth, Structural Change, and the Gains from the Uruguay Round. Review of International Economics, forthcoming.

Baldwin, R. E. (1992). Measurable Dynamic Gains From Trade, Journal of Political Economy, 100 (February): 162-174.

Baldwin, R. E., Francois, J. F. and Portes, R. (1997). The costs and benefits of eastern enlargement: The impact on the EU and central Europe. Economic Policy, 24, 127-170.

Brenton, P. and Gros, D. (1993). The Budgetary Implications of EC Enlargement. CEPS London. Working Paper No. 78.

Cox, D. and Harris, R. (1985). Trade Liberalization and Industrial Organisation: Some Estimates for Canada, Journal of Political Economy, 93, 115-145.

De Melo, J. and Robinson, S. (1989). Product differentiation and the treatment of foreign trade in computable general equilibrium models of small economies, Journal of International Economics 27: 489-497.

De Melo, J. and Tarr, D. (1992). A General Equilibrium Analysis of U.S. Foreign Trade Policy. Cambridge, Massachusetts: MIT Press.

European Commission (1995), Agricultural Situation and Prospects in the Central and Eastern European Countries: Summary Report. DGVI, Brussels.

European Commission (1997a). Agenda 2000, http://www-europa.eu.int/comm/agenda2000.

European Commission (1997b). The Agricultural Situation in the European Union 1996 Report. 
Luxembourg: Office for Official Publications of the European Communities.

European Commission (1998). Prospects for Agricultural Markets 1998-2005, http://europa.eu.int/ en/comm/dg6/new/caprep/prospects/fullrep/index.htm.

Francois, J., McDonald, B. and Nordström, H. (1996). A user's guide to Uruguay Round Assessments. Centre for Economic Policy Research, London. Discussion Paper Series, No. 1410.

Francois, J., and Shiells, C. R. (1994). Modeling Trade Policy: Applied General Equilibrium Models of North American Free Trade, Cambridge: Cambridge University Press.

Frandsen, S.E., Jensen H. G. and. Vanzetti D. M. (1998). Expanding Fortress Europe, Implications of European enlargement for non-member regions. Danish Institute of Agricultural and Fisheries Economics, Copenhagen. Working Paper Series, forthcoming.

GATT (1994a). Final Act embodying the results of the Uruguay Round of Multilateral Trade Negotiations, Geneva.

GATT (1994b). Uruguay Round of Multilateral Trade Negotiations. Legal Instruments Embodying the results of the Uruguay Round of Multilateral Trade Negotiations Done at Marrakesh on 15 April 1994.Schedules LXXX: European Communities, 19.

Gehlhar, M. and Frandsen S. E. (1998). Trade Elasticities, Aggregation Bias and Welfare Effects in the GTAP Model. Poster, First Annual conference on Global Economic Analysis, June Purdue University, USA.

Harrison, W. J. and Pearson, K. R. (1996). Computing Solutions for Large General Equilibrium Models using GEMPACK, Computational Economics, 9, 83-127.

Hertel, T. W. (ed.) (1997a). Global Trade Analysis: Modeling and Applications. Cambridge: Cambridge University Press.

Hertel, T., Brockmeier, M. and Swaminathan, P. (1997b). Sectoral and Economywide Analysis of Integrating Central and East European Countries into the European Union: Implications of Alternative Strategies. European Review of Agricultural Economics, 24 (1997).

Ingco, M.D. (1995). Agricultural Trade Liberalisation in the Uruguay Round: One-Step Forward, One Step Back? Supplementary Paper for the Conference on the Uruguay Round and the 
Developing Economics, January 26-27, 1995.

Jensen, H.G., S. E. Frandsen and C. F. Bach (1998). Agricultural and Economic-Wide Effects of European Enlargement: Modelling the Common Agricultural Policy, Danish Institute of Agricultural and Fisheries Economics, Copenhagen. Working Paper Series, forthcoming.

Martin, W. and Winters L. A. (eds.) (1996). The Uruguay Round and the Developing Countries. Cambridge: Cambridge University Press.

McDougall, R. A. (1998). Global Trade, Assistance, and Protection: The GTAP 4 Database. Center for Global Trade Analysis, Purdue University, Indianna, USA, forthcoming.

Rodrik, D. (1997). The costs and benefits of eastern enlargement: The impact on the EU and central Europe: Discussion. Economic Policy, 24, 170-173.

Slater, J. and Atkinson N. (1995). The Common Agricultural Policy and EU Enlargement to the East. UK Ministry of Agricultural, Fisheries and Food.

Tangermann, S. and Josling, T. E. (1994). Pre-Accession Agricultural Policies for Central Europe and the European Union, Final Report for the European Commission, DG I, Brussels.

Tangermann, S. (1996). Reforming the CAP: A Prerequisite for Eastern Enlargement. Paper presented at Kiel Week Conference.

Tyers, R. (1993). Economic Reform in Europe and the Soviet Union: Implications for International Food Markets. IFPRI, Washington.

Tyers, R. (1994). Agricultural Sector Impacts of Economic Reform in Greater Europe and the Former Soviet Union, in Hartmann, M. Schmitz, P.M. and V. Witzke, H (eds): Agricultural Trade and Economic Integration in Europe and North America, Kiel, pp. 55-89.

Venables, A. and Smith A. (1988). Trade and Industrial Policy under Imperfect Competition, Economic Policy, 1, 622-672.

WTO, (1998). Notification. Committee on Agriculture. World Trade Organisation. http://www.wto.org/wto/ddf/e 
-24 - 
Annex 1. Experimental design - overview

\begin{tabular}{|c|c|}
\hline Abbr. & Description \\
\hline S-1 & $\begin{array}{l}\text { BASELINE SCENARIO 1995-2005 } \\
\text { Projections } \\
\text { Shocks to factor endowments, population and GDP } \\
\text { Specific shocks to total factor productivity in crops and livestock. } \\
\text { Shocks to total factor productivity in all other sectors implicit in GDP shocks. } \\
\text { Uruguay Round Agreement } \\
\text { Abolition of export quota tax equivalents according to the Agreement on Textiles and Clothing. } \\
\text { Tariff reductions according to Agreement - tariff schedules compared with } 1995 \text { protection data. } \\
\text { Export subsidy rates are adjusted in line with changes in tariff rates. } \\
\text { If export subsidy commitment (either in value or quantity) is binding, the export subsidy rate is further reduced. } \\
\quad \text { EU-15: Wheat: Export subsidies abolished due to quantitative Commitment. } \\
\quad \text { Coarse grains: Export subsidy rate reduced due to quantitative Commitment. } \\
\quad \text { Other animal products: Export subsidy rate reduced due to budgetary outlay Commitment. } \\
\text { Additional CAP instruments } \\
\text { Fixed quota for raw milk and sugar cane and beet production } \\
\text { Hectare premiums to wheat, coarse grains and other crops are allocated per hectare within the bounds of the } \\
\text { total base area of 53,563,000 ha while the total budgetary outlay to oilseeds is fixed due to overshooting of the } \\
\text { Blair House Agreement base area. } \\
\text { Set-aside rate is held constant at the } 1995 \text { level (14,4 per cent). Livestock premiums to suckling cows, male } \\
\text { animals, steers and breeding ewes are fixed at total budgetary outlay. All premiums are deflated by } 2 \text { per cent } \\
\text { as these are fixed in nominal terms. } \\
\text { Central and Eastern European Countries: } \\
\text { Bilateral border taxes are removed between the individual Central and Eastern European Countries } \\
\text { (preparations for joining the EU). The effects of the Europe Agreements are not explicitly taken into account. }\end{array}$ \\
\hline S-2 & $\begin{array}{l}\text { CEEC INTEGRATION AFTER S-1, } 2005 \\
\text { Removal of all tariffs and export subsidies/taxes between the EU-15 and the CEEC. } \\
\text { Fixed milk and sugar production (quota regime) in EU-15 and CEEC if binding. } \\
\text { CEEC: External tariffs and export and output subsidies/taxes equalised with those in the EU-15. } \\
\text { Hectare premiums to wheat, coarse grains, other crops and oilseeds are given as fixed budgetary outlays to a } \\
\text { historic base area of } 26,934,000 \text { ha ( } 1994 \text { area). } \\
\text { Quota levels for milk and sugar in CEEC are established on the basis on production in } 2005 \text { prior to accession. } \\
\text { Set-aside rate is equalised with EU-15 rate ( } 14.4 \text { per cent decrease in land productivity). } \\
\text { Livestock premiums are given as fixed budgetary outlays based on historic livestock figures (1994). Transfers } \\
\text { from the EU-15 to the CEEC equal to export subsidies, output subsidies and hectare/livestock premiums less } \\
\text { import tariffs and } 0.65 \text { per cent of GDP in the CEEC. }\end{array}$ \\
\hline S-3 & $\begin{array}{l}\text { AGENDA 2000, 1995-2005 } \\
\text { Projections and agricultural policies in all region } \\
\text { As in S-1, however, TFP in all sectors is shocked exogenous with growth rate found in S-1 with GDP } \\
\text { endogenous. } \\
\text { EU-15: } \\
\text { Generally as in S-1, however, further cuts in border protection representing the proposed reductions in } \\
\text { intervention prices for cereals, bovine meat and dairy product. } \\
\text { Compensatory payments to arable crops are further adjusted in accordance with the proposal. All hectare } \\
\text { premiums are given per hectare due to the abolishment of the Blair House Agreement on oilseeds within the } \\
\text { bounds of the total base area of } 53,563,000 \text { ha. } \\
\text { All livestock premiums are adjusted in accordance with the proposal and new premiums to dairy cows. } \\
\text { The set-aside rate is reduced from } 14,4 \text { to } 0 \text { per cent. } \\
\text { The total milk quota increased by } 2 \text { per cent. }\end{array}$ \\
\hline S-4 & $\begin{array}{l}\text { CEEC INTEGRATION AFTER S-3, } 2005 \\
\text { As in Scenario } 2 \text { given the agricultural policy in the baseline S-3. }\end{array}$ \\
\hline
\end{tabular}

